\title{
THIRD INTER-AMERICAN MEETING OF RED CROSS INFORMATION AND PUBLIC RELATIONS DIRECTORS
}

"The Red Cross will not be able to play its role properly in the world today unless its action is understood and upheld by public opinion. It follows that the supply of information and the maintenance of good public relations are of primary significance, at national and international level. Yet in general the efforts made in this field are still inadequate. In some countries good progress has been made; but it must be admitted that in many others the conditions do not by any means exist to enable the public to follow and take part in the activities of the Red Cross and to espouse the humanitarian principles which guide the movement. Nor are these inadequacies found only in Latin America: they exist all over the world." These are the impressions summed up at the third interAmerican meeting of public relations directors, held in Mexico City from 5 to 10 September last.

Organized with skill by the Mexican Red Cross, in particular by Mrs. Irma de Fautsch, President of the National Committee for Public Relations, this third meeting was attended by only a small number of representatives of National Societies, seven in all. Apart from the host Society, there were public relations experts from the Red Cross Societies of Brazil, Colombia, Costa Rica, Ecuador, El Salvador and Guatemala. The League was represented by Mr. Ricardo Bermudez, Delegate General for Latin America, and Mrs. Toni Jordana, of the Spanish Red Cross, a public relations consultant. Mr. Modoux represented the ICRC.

Among the numerous items on the agenda, the representatives of the National Societies examined particularly the impact of the information efforts of the League and the ICRC in times of major catastrophes and international crises. While agreeing that it was useful for Societies to receive news at once from Geneva on the operations taking place, the participants emphasized how vital it was for the information services of the League and the ICRC to make contact in the disaster area or the combat zone, with the special correspondants of the international 
press. These on-the-spot contacts, as the recent experience of the ICRC in Lebanon has shown, are the only way to make sure that Red Cross operations in an emergency are promptly and fully reported.

With regard to the dissemination of knowledge of Red Cross principles and the Geneva Conventions, the National Societies' representatives, after having heard the ICRC delegate's report on the situation in Latin America, noted with satisfaction that the efforts being made, though still in the initial stages, were beginning to show results. For example, in several Latin American countries, working parties had been formed to further international humanitarian law in various quarters, especially in the armed forces and higher educational establishments. During the debate, Mrs. Margarita Escallon de Mallarino, public relations director of the Red Cross of Colombia, announced that her Society would be organizing, next November, a large-scale national seminar on the dissemination of the Geneva Conventions, to be attended by eminent experts on public international law and senior members of the Government and the army.

The meeting also debated various questions of a more technical nature, such as the recruiting campaigns to gain members; World Red Cross Day; the organization of public relations services and their place in the organizational structure of the National Societies; and fundraising drives. On the last-named subject, all those present were favourably impressed by the new "Guide to Fund-Raising" issued by the League in co-operation with some of the European National Societies. The guide was all the more welcome since it specifically met a definite need on the part of many National Societies.

Finally, the participants agreed to meet again in two years' time in Caracas, where the Inter-American Red Cross Conference will take place, with the hope that in the meantime those National Societies of Latin America that have still not appointed a director of information will have remedied this lack. For, more than ever before, the continued growth of the Red Cross largely depends on its relations with the general public, which reaps the benefit of its action in time of need, and which in return provides it with the financial resources it requires. 